\title{
PENGEMBANGAN PERPUSTAKAAN DIGITAL DI PROGRAM STUDI PENDIDIKAN TIK IKIP PGRI PONTIANAK
}

\author{
Ratih Widya Nurcahyo ${ }^{1)}$, Unung Verawardina ${ }^{2)}$, Ferry Marlianto ${ }^{3)}$ \\ ${ }^{1,2,3}$ Prodi TIK, IKIP PGRI Pontianak \\ e-mail : $\underline{1}$ ratihwidya@gmail.com, ${ }^{2}$ unung@gmail.com, ${ }^{3}$ ferrymarlianto@yahoo.co.id
}

\begin{abstract}
This research is entitled "Digital Library Development in Information Technology and Computer Education Study Program (P.TIK) IKIP PGRI Pontianak". The type of research used is research and development $(R \& D)$. The development model used is ADDIE. The subject of product trials for the implementation of digital libraries in this study were semester VI students. For small group trials conducted on a limited number of 15 students, consisting of students who have high, medium and low abilities, and field trials were conducted on 32 students. The data collection tool used in this study was a questionnaire. From the results of the study for the results of the feasibility validation of digital library products by media experts, the average score of 3.53 criteria was very good. Results from material experts obtained an average of 3.58 on the criteria very well. While the results of librarian experts obtained an average of 3.54 on the criteria very well. For the results of the digital library trials which were carried out limitedly on 15 students of the ICT Study Program IKIP-PGRI Pontianak obtained an average of 3.43 on the criteria very well. For the results of the best response obtained by 3.39 than the criteria good. Conclusions from the results of validation, trials and responses prove that digital libraries are feasible to use and can assist students in supporting lectures
\end{abstract}

Keywords: Development, Digital Library, ADDIE

\section{INTISARI}

Penelitian ini berjudul "Pengembangan Perpustakaan Digital di Program Studi Pendidikan Teknologi Informasi dan Komputer (P.TIK) IKIP PGRI Pontianak". Jenis penelitian yang digunakan adalah penelitian pengembangan atau Research and Development ( $\mathrm{R} \& \mathrm{D})$. Model pengembangan yang digunakan adalah ADDIE. Subjek uji coba produk untuk implementasi perpustakaan digital dalam penelitian ini adalah mahasiswa semester VI (enam). Untuk uji coba kelompok kecil dilakukan kepada mahasiswa secara terbatas berjumlah 15 orang, yang terdiri dari mahasiswa yang mempunyai kemampuan tinggi, sedang dan rendah, dan uji coba lapangan dilakukan kepada 32 mahasiswa. Alat pengumpul data yang digunakan dalam penelitian ini adalah angket. Dari hasil penelitian untuk hasil validasi kelayakan produk perpustakaan digital oleh ahli media memperoleh rata-rata sebesar skor 3,53 kriteria sangat baik. Hasil dari ahli materi diperoleh rata-rata sebesar 3,58 pada kriteria sangat baik. Sedangkan hasil dari ahli pustakawan diperoleh rata-rata sebesar 3,54 pada kriteria sangat baik. Untuk hasil uji coba perpustakaan digital yang dilakukan secara terbatas pada 15 mahasiswa Prodi TIK IKIP-PGRI Pontianak diperoleh ratarata sebesar 3,43 pada kriteria sangat baik. Untuk hasil respon terbut diperoleh sebesar 3,39 dari pada kriteria baik. Kesimpulan dari hasil validasi, uji coba dan respon membuktikan bahawa perpustakaan digital layak digunakan dan dapat memebantu mahasiswa dalam menunjang perkuliahan.

Kata kunci : Pengembangan, Perpustakaan Digital, ADDIE 


\section{PENDAHULUAN}

Perpustakaan adalah institusi yang menyediakan koleksi bahan pustaka tertulis, cetak dan terekam sebagai pusat sumber informasi yang dapat digunakan dalam pendidikan, penelitian maupun rekreasi intelektual [1]. Perpustakaan dapat dimanfaatkan sebagai tempat untuk mencari sumber informasi dan referensi oleh masyarakat. Pendidikan wajib memiliki perpustakaan. Karena dengan perpustakaan di lembaga pendidikan khususnya di lingkungan perguruan tinggi dapat membangun kecerdasan dan membuka cakrawala pengetahuan untuk mahasiswa [2-3].

Melalui perpustakaan digital pengguna dapat mengunduh sumber belajar yang tersedia di perpustakaan digital. Koleksi di perpustakaan digital bervariasi dapat berupa teks, audio, gambar, selain itu juga menghemat biaya. Pada perpustakaan konvensional mengharuskan mahasiswa untuk datang ke perpustakaan mencari sumber informasi yang diperlukan, sedangkan melalui perpustakaan digital mahasiswa dapat mendapatkan sumber informasi melalui akses internet sehingga lebih efektif dan efesien. Selain itu perpustakaan digital mampu memberikan layanan yang menyenangkan non stop dapat diakses di mana dan kapan saja tanpa batasan ruang dan waktu. Tidak lagi mahasiswa terpaku pada jam opersional pada perpustakaan konvensional. Untuk membangun sebuah perpustakaan digital maka diperlukan pemahaman tentang perpustakaan dan berfokus pada penggunaan teknologi informasi.

Permasalahan yang terjadi di Program Studi Pendidikan TIK yakni perpustakaan saat ini yang dimiliki masih menyatu dengan perpustakaan pusat IKIP PGRI Pontianak. Masih kurangnya sumber belajar untuk menunjang proses pembelajaran di kelas bagi mahasiswa dan dosen, terlebih di zaman informasi saat ini diperlukan beragam referensi. Selain itu belum digunakanya perpustakaan digital dalam manejemen sistem otomatis perpustakaan yang efektif dan efesien. Berdasarkan masalah tersebut, maka dipandang sangat perlu dibuatnya produk perpustakaan digital yang berdasarkan analisis dan desain yang telah diteliti sebelumnya. Diharapkan dengan diimplementasi dan dibuatkanya perpustakaan digital dapat membantu layanan mahasiswa dalam mencari informasi yang tidak dibatasi dengan koleksi tertentu saja, misalnya berupa buku-buku terbaru, artikel, jurnal, e-book maupun skripsi dan lainnya, sehingga menjadi lebih efektif dan efesien. Selain itu memudahkan manejemen perpustakaan seperti pembuatan katalog, inventarisasi, pengaturan sistem, menyediakan informasi dalam format digital dan sebagainya.

Pengembangan perpustakaan digital harus dirancang dengan baik, oleh karena itu dalam penelitian ini menggunakan model ADDIE yang memiliki tahapan Analysis, Design, Development, Implementation dan Evaluation. Tujuan dari penelitian ini melanjutkan dari hasil penelitian yang telah dilakukan sebelumnya mengenai analisis dan perancangan perpustakaan digital, yang kemudian dikembangkan dengan membuat perpustakaan digital sesuai kebutuhan, mengetahui kelayakan produk, implementasi perpustakaan digital, serta mengetahui respon mahasiswa setelah menggunakan perpustakaan digital.

\section{PENDEKATAN PEMECAHAN MASALAH}

Teknologi informasi dan komunikasi (TIK) merupakan bagian dari teknologi informasi. Teknologi informasi berkaitan dengan penggunaan alat, proses, memanipulasi, pengelolahan informasi, dan penyimpanan. Teknologi informasi mencakup perangkat keras dan perangkat lunak untuk melaksanakan satu atau sejumlah tugas pemrosesan data seperti menangkap, mentransmisikan, menyimpan, mengambil, memanipulasi atau menampilkan data [4].

TIK telah memasuki ranah pendidikan yang telah menyebar secara luas, yang memungkinkan dengan adanya TIK memudahkan pelaksanaan pembelajaran lebih cepat mencari informasi. Melalui TIK dapat melakukan proses pembelajaran yang tidak terbatas waktu dan tempat seperti $E$ book, E-Learning, E-laboratory, E-education, Elibrary, dan sebagainya [5]. Dalam hal ini penggunaan TIK berfokus pada penggunaan $e$ library atau yang biasa dikenal juga dengan istilah perpustakaan digital (digital library) yang memudahkan mahasiswa mencari sumber informasi, bahan ajar, buku-buku dan sebagainya yang dapat dilakukan di mana dan kapan saja secara fleksibel.

Perpustakaan merupakan sumber informasi yang setiap saat dapat digunakan oleh pengguna [6]. Kumpulan yang terdapat di dalam perpustkaan tidak hanya berupa buku, dapat bahan cetak seperti majalah, laporan, prosiding, skripsi, dan kumpulan naskah lainnya. Perpustakaan sangat penting karena dipergunakan sebagai sumber untuk menunjang pelaksanaan proses belajar-mengajar 
[6]. Oleh karena itu pentingnya perpustakaan karena merupakan wadah yang berkualitas dalam menggali ilmu bagi peserta didik dan pengajar dalam pembelajaran.

Istilah perpustakaan digital (digital library) dikenal pula sebagai perpustakaan elektronik $(e-$ library), yakni perpustakaan yang didukung dengan menggunakan teknologi secara elektronik. Perpustakaan digital merupakan koleksi berupa sumber informasi yang disajikan dengan bentuk digital tentu dalam pembuatanya dijembatani dengan teknologi informasi. A digital library is a managed collection of information, with associated services, where the information is stored in digital formats and accessible over a network [7]. Diuraikan bahwa perpustakaan digital adalah suatu penyimpanan koleksi informasi digital yang dimanajemen secara sistematis, yang disajikan dan dapat diakses menggunakan jaringan komputer. The digital library federation menyatakan perpustakaan digital adalah:

Organizations that provide resources, including the specialized staff, to select, structure, offer intellectual access to, interpret, distribute, preserve the integrity of and ensure the persistence over time of collections of digital works so that they are readily and economically available for use by a defined community or set of communities [8].

Uraian tersebut berarti bahwa perpustakaan digital merupakan organisasi yang menyediakan sumber informasi, termasuk staf khusus, untuk memilih, menyusun, menyediakan akses, menginterpretasi, mendistribusikan, mempertahankan integritas, dan memastikan ketergantungan koleksi digital dalam jangka waktu tertentu sehingga menjadi mudah dan ekonomis untuk komunitas pengguna perpustakaan.

Seorang pustakawan harus bekerja sama dengan pengajar, agar pengguna dapat secara mandiri untuk mencari sumber belajar yang tersedia dalam teknologi informasi [9]. Maka dengan perpustakaan digital yang dikemas dalam bentuk $w e b$, peserta didik dapat mencari informasi secara mudah berkaitan materi pelajaran yang diberikan oleh pengajar. Maka dari itu peran pustakawan sangat penting dalam melakukan pengelolaan perpustakaan.

\section{Metode}

Metode penelitian umumnya dikenal dengan cara dalam melaksanakan penelitian. Jenis penelitian yang digunakan adalah penelitian pengembangan atau Research and Development $(\mathrm{R}$ \& D). Model pengembangan yang digunakan adalah ADDIE. Adapun tahapan pengembangan meliputi Analysis (Analisis), Design (Desain),
Development (Pengembangan), Implementation (Implementasi) dan Evaluation (Evaluasi).Konsep dari ADDIE dapat dilihat sebagai berikut [10]:

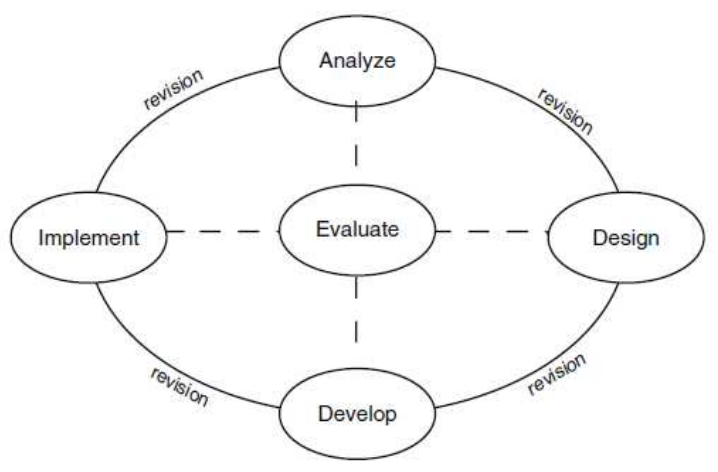

Gambar 1. Konsep $A D D I E$

Dipilihnya model pengembangan ADDIE karena dapat mendukung pengembangan dan implementasi. Tahapan pengembangan produk dalam penelitian ini mengimplementasikan dan membuat produk berdasarkan hasil dari analisis dan perancangan perpustakaan digital dari penelitian sebelumnya.

Subjek penelitian ini terdiri dari subjek pengembangan perpustakaan digital untuk memvalidasi kelayakan produk dan subjek uji coba produk yakni mahasiswa dan dosen yang akan diimplementasi perpustakaan digital.

\section{Subjek Pengembangan}

Subjek pengembangan dalam penelitian ini adalah ahli media yang menguasi dibidang pembuatan web, ahli materi dan ahli pustakawaan tentang perpustakaan untuk melakukan kelayakan produk perpustakaan digital. Adapun ahli media tersebut adalah dua orang dosen Prodi. TIK IKIP PGRI Pontianak, dan ahli pustakawan. Uji kelayakan perpustakaan digital ini dengan memberikan angket kelayakan produk perpustakaan digital kepada para ahli tersebut (dosen). Setelah diujikan kelayakan perpustakaan digital, kemudian dilakukan revisi sesuai rekomendasi perbaikan dan saran para ahli

2. Subjek Uji Coba Produk

Subjek uji coba produk untuk implementasi perpustakaan digital dalam penelitian ini adalah mahasiswa semester VI (enam). Untuk uji coba kelompok kecil dilakukan kepada mahasiswa secara terbatas berjumlah 15 orang, yang terdiri dari mahasiswa yang mempunyai kemampuan tinggi, sedang 
dan rendah, dan uji coba lapangan dilakukan kepada 32 mahasiswa.

Teknik pengumpulan data merupakan langkah yang paling utama dalam penelitian, karena tujuan utama dari penelitian adalah mendapatkan data. Tanpa mengetahui teknik pengumpulan data, maka peneliti tidak akan mendapatkan data yang memenuhi standar data yang ditetapkan [11]. Oleh karena itu pengumpulan data diperlukan untuk mendapatkan data yang sesuai dalam penelitian. Teknik pengumpulan data yang digunakan pada penelitian ini adalah Teknik dokumentasi dan Teknik komunikasi tidak langsung.

Alat pengumpul data yang digunakan dalam penelitian ini adalah angket. Angket merupakan suatu teknik dalam mengumpulkan data dengan memberikan suatu petanyaan yang secara tertulis maupun dijawab secara langsung [12]. Penelitian ini menggunakan angket berisi pertanyaan tertutup tentang aspek-aspek kelayakan perpustakaan digital yang akan dikembangkan.

\section{Teknik Analisis Data}

1. Untuk mengembangkan perpustakaan digital yakni mulai membuat dan mendesain perpustakaan digital sesuai analisis dan perancangan yang telah dilakukan pada penelitian sebelumnya, maka dari itu pengembangan dilakukan bersumber pada flowchart yang telah dirancang.

2. Data yang diperoleh melalui angket kelayakan produk perpustakaan digital dari ahli media dan ahli pustakawan, serta hasil uji coba produk maka hasilnya dihitung secara kuantitatif berupa angka rating scale 1-4 kemudian kriteria nilai dikonversi dalam skala 5, kemudian di prosentasekan sebagai berikut ini:

a) Konversi skor ideal dalam skala 5 dapat dilihat pada tabel 1 [13].

Tabel 1. Kategori Kelayakan Produk

\begin{tabular}{cc}
\hline Interval & Kriteria \\
\hline$X>\bar{X}+1,8 s b$ & Sangat baik \\
\hline $\bar{X}+0,6 s b<X \leq \bar{X}$ & Baik \\
$+1,8 s b$ & \\
\hline $\bar{X}-0,6 s b<X \leq \bar{X}$ & Cukupbaik \\
$+0,6 s b$ & \\
\hline $\bar{X}-1,8 s b<X \leq \bar{X}$ & Kurang \\
$-0,6 s b$ & \\
\hline$X \leq \bar{X}-1,8 s b$ & Sangat kurang \\
\hline
\end{tabular}

Keterangan:

$$
\begin{aligned}
\frac{\mathrm{X}}{X} & =\text { total nilai dari validator } \\
& =\text { rata-rata nilai ideal } \\
& =\frac{1}{2}(\text { nilai maksimal ideal }+ \text { nilai minimal ideal }) \\
s b & =\text { simpangan baku ideal } \\
& =\frac{1}{6}(\text { nilai maksimal ideal }- \text { nilai minimal ideal }) .
\end{aligned}
$$

b) Perhitungan prosentase rating scale sebagai berikut [12]:

$$
\mathrm{P}=\frac{\text { Skor hasil pengumpulan data }}{\text { Jumlah skor kriterium }} X 100
$$

$$
\begin{aligned}
& \text { Keterangan: } \\
& \mathrm{P}=\begin{array}{l}
\text { Presentase Skor kriterium }=\text { skor } \\
\text { tertinggi } \mathrm{x} \text { jumlah butir } \mathrm{x} \text { jumlah } \\
\text { responden }
\end{array}
\end{aligned}
$$

Sedangkan hasil angket yang berupa saran dan rekomendasi perbaikan maka akan dilakukan revisi pada produk sesuai dengan yang dituliskan oleh ahli media, ahli materi dan ahli pustakawan.

3. Menganalisis hasil angket respon mahasiswa setelah implementasi perpustakaan digital dengan memberikan rentang skor skala 1-4. Menghitung jumlah skor dan digambarkan melalui statistik deskriptif, serta mengkategorikan hasil kecendrungan angket menurut Mardapi (2008:123).

\section{HASIL DAN PEMBAHASAN}

Pengembangan perpustakaan digital di Prodi Pendidikan TIK IKIP PGRI Pontianak mengadopsi model pengembangan produk dari ADDIE yang meliputi tahapan Analysis (analisis), Design (desain), Development (pengembangan), Implementation (implementasi) dan Evaluation (evaluasi). Adapun penjelasanya seagai berikut:

\section{Analisis Kebutuhan Perpustakaan Digital}

Analisis kebutuhan perpustakaan digital di Prodi Pendidikan TIK IKIP PGRI Pontianak, dilakukan dengan tahapan analisis yang diperoleh sebagai berikut:

Tahapan pertama yang dilakukan yakni analisis, namun sebelumnya terlebih dahulu menganalisis permasalahan yang terjadi, yang kemudian menganalsis kebutuhan yang diinginkan untuk mencari solusi. Masalah yang dihadapi mahasiswa dalam mencari sumber belajar sangat terbatas, kurangnya jam 
operasional perpustakaan, tidak lengkapnya koleksi buku diperpustakaan konvensional, lambatnya membuat kartu anggota perpustakaan, serta administrasi perpustakaan masih bersifat manual.

Sedangkan dosen kesulitan dalam menyebarluaskan materi ajar untuk mahasiswa, dosen juga kesulitan mencari buku referensi yang efektif dan efisen serta fleksibel untuk dicari. Perpustakaan yang ada masih bersifat konvensional belum secara digital, sehingga tidak bisa diakses secara bebas dimana dan kapan saja tanpa batas ruang dan waktu. Perpustakaan yang ada belum maksimal sebagai sumber belajar, belum tersusun rapi seperti judul buku, ISBN, katalog, kartu anggota, dll.

Analisis kebutuhan untuk mengetahui kebutuhan yang dilakukan peneliti tentang analisis dan perancangan perpustakaan digital yang diinginkan Prodi Pendidikan TIK IKIP PGRI Pontianak khususnya mahasiswa, dan dosen seperti koleksi buku, keanggotaan, tampilan, desain, dan sebagainya. Untuk mengetahui analisis kebutuhan tersebut maka dilakukanya wawancara. Adapun hasil dari wawancara yang diperoleh yakni:

a. Analisis Kebutuhan Mahasiswa

Analisis kebutuhan mahasiswaa
yakni menginginkan pembuatan
perpustakaan digital yang menarik, adanya konten teks, dan gambar, yang dikemas menjadi sumber belajar pendukung yang dapat memotivasi mahasiswa untuk belajar. Kemudahan dalam mengakses perpustakaan digital, seperti perpustakaan yang tidak dibatasi jam operasional perpustakaan. Mahasiswa juga dapat mengunduh bahan yang tersedia di perpustakaan digital misalnya e-journal, $e$ book, buku referensi, dan artikel. Desain perpustakaan digital dibuat semenarik mungkin, koleksi buku diperpustakaan digital bervariasi dapat berupa teks, gambar, selain itu juga menghemat biaya. Dibuatnya kemudahan dalam mengakses kartu anggota yang menggunakan username dan password yang dapat menggunakan login menggunakan Nama dan NIM. Serta membutuhkan Counter pengunjung untuk memudahkan mahasiswa menggunakan perpustakan digital, dan memudahkan peminjaman dan pengembalian buku. b. Analisis Kebutuhan Dosen

Kebutuhan dosen untuk perpustakaan digital adalah membutuhkan perpustakaan digital dikemas secara online agar dapat diakase dimana dan kapan saja tanpa dibatasi jarak ruang dan waktu, maka membutuhkan koneksi internet. Dosen menginginkan koleksi buku-buku yang menunjang perkuliahan dimasukan ke dalam perpustaakaan digital, umumnya semua mata kuliah, namun diutamakan mata kuliah seperti pemrograman dan teknologi informasi dan komunikasi.

c. Analisis Kebutuhan Pustakawan

\begin{tabular}{lllr}
\multicolumn{2}{c}{ Membutuhkan data anggota } \\
perpustakaan, data operator yang \\
menjalankan perpustakaan digital.
\end{tabular}

Membutuhkan pengaturan keanggotaan perpustakaan digital yang tersistematasi. Koleksi buku disusun berdasarkan nomor panggilannya yang lebih tersistematis. Dibuat katalog secara lengkap dengan adanya sampul buku, sinopsis buku, penulis, penertbit, jumlah halaman, dan kategori buku. Selain itu perpustakaan digital dilengkapai dengan import data, eksport data. Ketersediaan sirkulasi untuk memudahkan transaksi peminjaman dan pengembalian buku, adanya denda.

Perpustakaan digital dengan ketersedian manajemen user untuk pengguna seperti hak akses, operator, dan pengaturan. Untuk memudahkan penggunaan perpustakaan digital dibutuhkan juga panduan dalam menggunakan perpustakaan digital tersebut, untuk memudahkan pengguna dalam tata cara pengoperasian perpustakaan digital. Dibutuhkan juga pelaporan untuk koleksi, laporan keanggotaan, laporan peminjaman serta laporan dalam bentuk statistik.

d. Analisis Kebutuhan Perpustakaan Digital Analisis sarana perpustakaan digital dengan tersedianya fasilitas teknologi informasi dan komputer, serta internet. Menganalisis lingkungan pendukung teknologi informasi dalam perkuliahan, maka untuk fasilitas telah tersedia dan memiliki fasilitas internet, bahkan tersedia fasilitas free hotspot untuk mahasiswa. Jadi mahasiswa lebih mudah mengakses sumber informasi secara leluasa. Dengan ketersedian teknologi dan informasi dan 
internet maka tepat dalam menunjang membuat perpustakaan digital. Prodi Pendidikan TIK IKIP PGRI Pontianak juga menyediakan fasilitas perangkat komputer, laboratorium komputer yang dapat dimanfaatkan oleh mahasiswa dan dosen memncari sumber belajar via online. Karena dapat memudahkan mahasiswa dan dosen mencari sumber belajar.

Berdasarkan hasil analisis kebutuhan pembuatan perpustakaan digital membutuhkan hardware dan software yang sesuai yang menunjang perpustakaan digital. Maka diperlukan hardware seperti perangkat komputer, server, data penyimpanan dengan space besar dan perangkat jaringan internet. Perpustakaan digital dibuat menggunakan bahasa pemrograman web seperti PHP, HTML. Karena berbasis web maka juga membutuhkan hosting dan domain, serta browser untuk menjalankan.

\section{Perancangan Perpustakaan Digital}

Perancangan perpustakaan digital di Prodi Pendidikan TIK IKIP PGRI Pontianak, dilakukan dengan tahapan desain yang diperoleh sebagai berikut:

\section{a. Tahap Design (Desain)}

Pada tahap ke dua dilakukanya desain yakni bersumber dari analisis kebutuhan yang kemudian didesain perancangannya. Maka diperlukan klarifikasi terhadap produk perpustakaan digital tentang spesifikasi yang didesain, sehingga produk tersebut sesuai dengan yang dibutuhkan. Pada desain produk perpustakaan digital terlebih dahulu mempersiapkan koleksi seperti, bukubuku, jurnal, majalah, artikel, e-journal dan e-book yang dimuat pada perpustakaan digital. Mengumpulkan semua materi dari berbagai sumber referensi dijadikan dasar dalam mengembangkan desain perpustakaan digital dengan membuat flowchart.. Flowchart perpustakaan digital dapat dilihat pada Gambar 2.

3. Tahap Development (Pengembangan)

Pada tahap ketiga dilakukanya pengembangan, dengan membuat perpustakaan digital Prodi PTIK IKIP PGRI Pontianak yang menyesuaikan kebutuhan mahasiswa dan dosen. Perpustakaan digital dibuat kemudian direview dan direvisi berdasarakan saran rekomendasi perbaiakan produk. Dilakukan validasi produk oleh ahli media, ahli materi, ahli perpustakaan (pustakawan) dan kemudian melakukan uji coba produk yang dikembangkan kepada mahasiswa sebagai pengguna perpustakaan digital.

a. Tampilan Beranda Perpustakaan digital Bagian beranda memuat informasi tentang perpustakaan digital

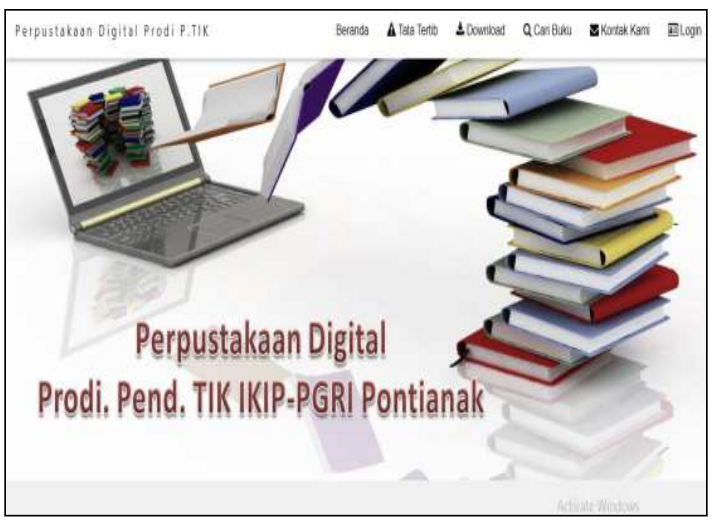

Gambar 3. Tampilan Beranda Perpustakaan Digital

b. Tampilan Halaman Login

Bagian ini memuat informasi username dan password jika ingin login.

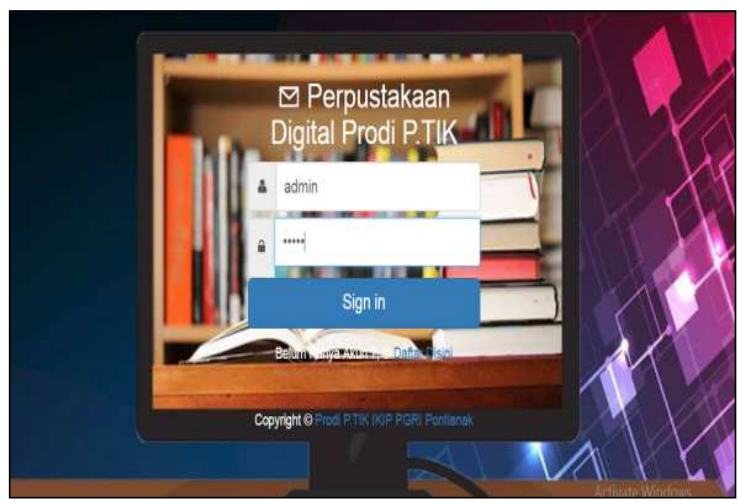

Gambar 4. Tampilan Halaman Login

4. Tahap Implementation (Implementasi)

Perpustakaan digital diujicobakan pada pada mahasiswa Prodi PTIK IKIP PGRI Pontianak. Implementasi kepada mahasiswa dilakukan di semester VI sebanyak 35 mahasiswa. Uji coba dilaksanakan pada bulan Juni 2018 yang dilaksanakan di ruang kelas dan mahasiswa membawa laptop masing-masing. 


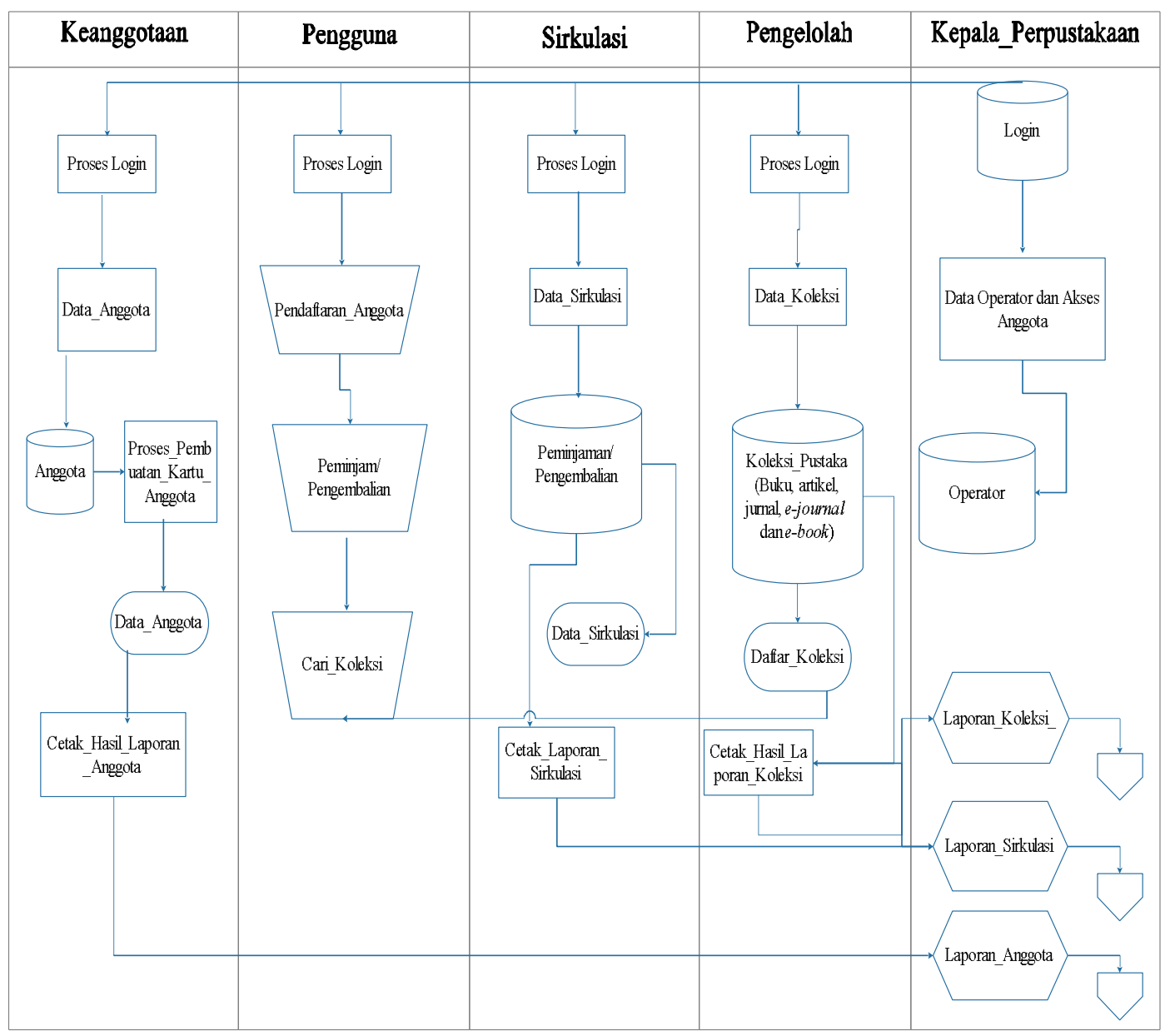

Gambar 2. Flowchart Perpustakaan Digital

Pelaksanaan uji coba perpustakaan digital sebagai berikut:

a. Menjelaskan tata cara penggunaan perpustakaan digital kepada mahasiswa.

b. Mempersilakan mahasiswa untuk menggunakan perpustakaan digital sebagai penunjang pembelajaran.

c. Setelah implementasi perpustakaan digital kepada mahasiswa selesai dilakukan, kemudian mahasiswa mengisi lembar respon uji coba produk perpustakaan digital yang akan digunakan sebagai bahan revisi perpustakaan digital tahap akhir.
5. Tahap Evaluation (Evaluasi)

Pada tahap evaluasi dilakukanya evaluasi perpustaaan digital yang dilakukan pada setiap tahapan berupa masukan dan perbaikan dalam setiap tahapan pengembangan. Selanjutnya produk perpustakaan digital dibuat dan dievaluasi berdasarjan hasil dari ahli media, ahli materi dan ahli pustakawan. Kemudian saat produk diimpelentasikan maka akan melakukan evaluasi kembali yakni uji coba terbatas pada produk dan uji coba produk kepada mahasiswa melalui evaluasi formatif dimana evaluasi dilakukan dengan mengetahui respon mahasiswa dan setelah menggunakan perpustakaan digital. 
a. Validasi perpustakaan digital

1) Hasil Validasi oleh Ahli Media

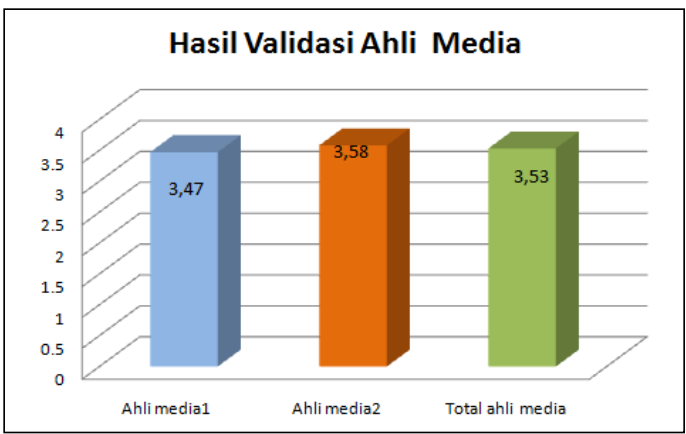

Gambar 5. Hasil Validasi Ahli Media

Dari gambar 5 disimpulkan bahwa hasil perhitungan ahli media 1 memperoleh rerata skor sebesar 3,47, dan ahli media 2 memperoleh rerata skor 3,58. Sedangkan hasil keseluruhan ahli media sebesar 3,53. Berdasarkan hasil tersebut maka perpustakaan digital dinyatakan kategori sangat baik.

2) Hasil Validasi oleh Ahli Materi

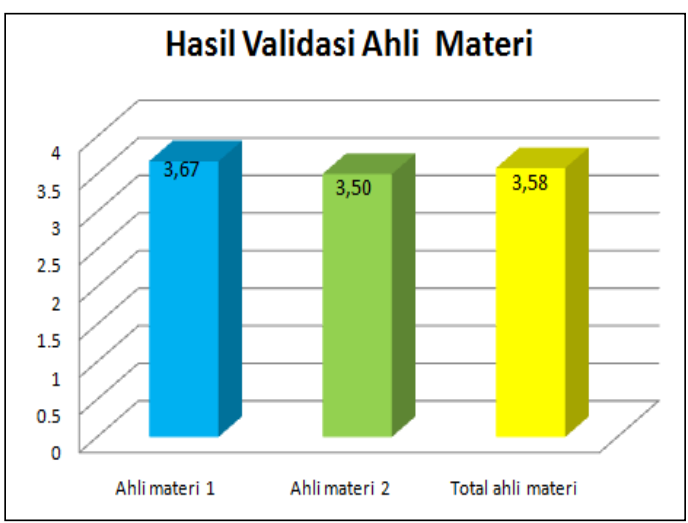

Gambar 6. Hasil Validasi Ahli Materi

Dari gambar 6 disimpulkan bahwa hasil perhitungan ahli materi 1 memperoleh rerata skor sebesar 3,67, dan ahli materi 2 memperoleh rerata skor 3,50. Sedangkan hasil keseluruhan ahli materi sebesar 3,58. Berdasarkan hasil tersebut maka perpustakaan digital dinyatakan kategori sangat baik.
3) Hasil Validasi oleh Ahli Pustakawan

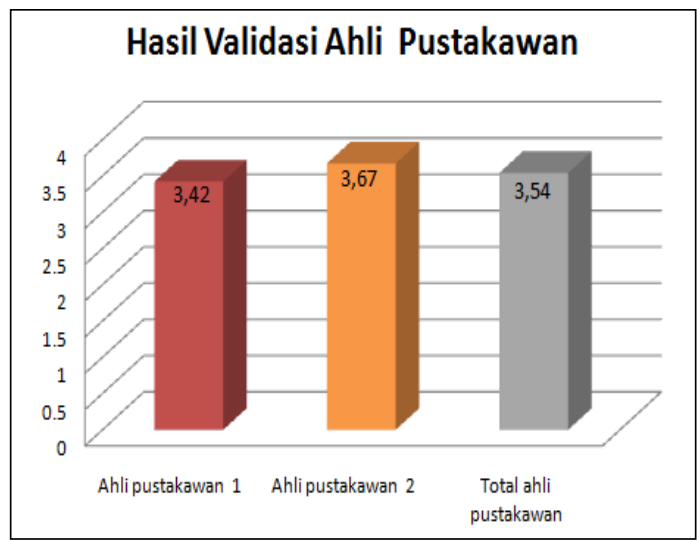

Gambar 7. Hasil Validasi Ahli Pustakawan

Dari gambar 7 disimpulkan bahwa hasil perhitungan ahli pustakawan 1 memperoleh rerata skor sebesar 3,42, dan ahli pustakawan 2 memperoleh rerata skor 3,67. Sedangkan hasil keseluruhan ahli pustakawan sebesar 3,54. Berdasarkan hasil tersebut maka perpustakaan digital dinyatakan kategori sangat baik.

4) Hasil Ujicoba untuk mengetahui respon

Dari data pada table 2 diperoleh hasil respon mahasiswa setelah menggunakan perpustakaan digital, maka diperoleh jumlah keseluruhan respon dengan rerata skor sebesar 3,39 dengan kategori baik, dan persentase sebesar $85,39 \%$. 
Tabel 2. Hasil Respon

\begin{tabular}{|c|c|c|c|}
\hline No & Skor & Rerata Skor & Ketgori \\
\hline 1. & 39 & 3,00 & Baik \\
\hline 2. & 41 & 3,15 & Baik \\
\hline 3. & 42 & 3,23 & Baik \\
\hline 4. & 24 & 3,56 & Sangat Baik \\
\hline 5. & 43 & 3,31 & Baik \\
\hline 6. & 44 & 3,38 & Baik \\
\hline 7. & 44 & 3,38 & Baik \\
\hline 8. & 48 & 3,08 & Baik \\
\hline 9. & 44 & 3,38 & Baik \\
\hline 10. & 45 & 3,46 & Sangat Baik \\
\hline 11. & 45 & 3,46 & Sangat Baik \\
\hline 12. & 49 & 3,77 & Sangat Baik \\
\hline 13. & 47 & 3,62 & Sangat Baik \\
\hline 14. & 43 & 3,31 & Baik \\
\hline 15. & 44 & 3,38 & Baik \\
\hline 16. & 41 & 3,15 & Baik \\
\hline 17. & 44 & 3,38 & Baik \\
\hline 18. & 40 & 3,08 & Baik \\
\hline 19. & 46 & 3,54 & Sangat Baik \\
\hline 20. & 48 & 3,69 & Sangat Baik \\
\hline 21. & 47 & 3,62 & Sangat Baik \\
\hline 22. & 45 & 3,46 & Sangat Baik \\
\hline 23. & 44 & 3,38 & Baik \\
\hline 24. & 44 & 3,38 & Baik \\
\hline 25 . & 41 & 3,15 & Baik \\
\hline 26. & 42 & 3,23 & Baik \\
\hline 27. & 43 & 3,31 & Baik \\
\hline 28. & 46 & 3,54 & Sangat Baik \\
\hline 29. & 47 & 3,62 & Sangat Baik \\
\hline 30. & 48 & 3,69 & Sangat Baik \\
\hline 31. & 47 & 3,62 & Sangat Baik \\
\hline 32. & 44 & 3,38 & Baik \\
\hline \multicolumn{2}{|c|}{ Total skor } & \multicolumn{2}{|r|}{1421} \\
\hline \multicolumn{2}{|c|}{ Persentase } & \multicolumn{2}{|r|}{$85,39 \%$} \\
\hline \multicolumn{2}{|c|}{$\begin{array}{c}\text { Rerata skor } \\
\text { akhir }\end{array}$} & \multicolumn{2}{|r|}{3,39} \\
\hline \multicolumn{2}{|c|}{ Kategori Skor } & \multicolumn{2}{|r|}{ Baik } \\
\hline
\end{tabular}

\section{KESIMPULAN}

Kesimpulan dari hasil penelitian yakni perpustakaan digital Prodi PTIK IKIP PGRI Pontianak dikembangkan secara digital berbasis web yang dapat diakses secara online. Adapun pengembanga produk dilakukan dengan 5 tahapan yakni tahap analisis, desain, pengembangan, implementasi dan evaluasi. Untuk hasil hasil validasi kelayakan produk perpustakaan digital oleh ahli media memperoleh rata-rata sebesar skor 3,53 kriteria sangat baik. Hasil dari ahli materi diperoleh rata-rata sebesar 3,58 pada kriteria sangat baik. Sedangkan hasil dari ahli pustakawan diperoleh rata-rata sebesar 3,54 pada kriteria sangat baik. Untuk hasil uji coba perpustakaan digital yang dilakukan secara terbatas pada 15 mahasiswa Prodi TIK IKIP-PGRI Pontianak diperoleh rata-rata sebesar 3,43 pada kriteria sangat baik. Untuk hasil respon terbut diperoleh sebesar 3,39 dari pada kriteria baik. Kesimpulan dari hasil validasi, uji coba dan respon membuktikan bahawa perpustakaan digital layak digunakan dan dapat memebantu mahasiswa dalam menunjang perkuliahan.

\section{DAFTAR PUSTAKA}

[1] Supriyanto, W. Teknologi Informasi Perpustakaan. Yogyakarta: Kanisius. 2008.

[2] Undang-Undang Republik Indonesia No. 20 Tahun 2003 tentang Sistem Pendidikan Nasional.

[3] Undang-Undang Republik Indonesia No. 19 Tahun 2005 tentang Standar Nasional Pendidikan.

[4] Rusman. dkk Pembelajaran Berbasis Teknologi Informasi dan Komunikasi. Jakarta: PT. Raja Grafindo Persada. 2011.

[5] Asmani, J.M. Tips Efektif Pemanfaatan Teknologi Informasi dan Komunikasi dalam Dunia Pendidikan. Yogyakarta: DIVA Press. 2011.

[6] Suwarno. Dasar-Dasar Ilmu Perpustakaan. Yogjakarta : Ar-Ruzz Media. 2007.

[7] Arms, W. Y. Digital Libraries. Cambridge, MA: MIT Press. 2000.

[9] Darmono. Manajemen Perpustakaan Sekolah. Malang: Bayumedia Publishing bekerjasama dengan Fakultas Sastra Universitas Negeri Malang. 2013.

[10] Branch, R.B. Instructional design: the addie approach: heidelberg.London: Springer. 2010.

[11] Sugiyono. Metode Penelitian Pendidikan. Bandung: Alfabeta. 2008.

[12] Sugiyono. Metode Penelitian Kuantitatif, Kualitatif dan R\&D. Bandung: Alfabeta. 2011.

[13] Widoyoko, E.P. Evaluasi Program Pembelajaran Panduan Praktis bagi Pendidik dan Calon Pendidik. Yogyakarta: Pustaka Pelajar. 2011. 
Internet :

[14] Waters, D.J. What are digital libraries? CLIR Issues, $1998 . \quad$ Website: http://www.clir.org/pubs/issues/issues04.HT ML. Diakses Bulan Februari. 